\title{
Vegetation record around a cement factory and the impact of dust pollution on crop productivity
}

\author{
Narahari Chapagain $^{1}$ and Min Raj Dhakal ${ }^{2 *}$ \\ ${ }^{I}$ Department of Plant Resources, Ministry of Forest and Soil Conservation, Kathmandu \\ P.O. Box 2270 \\ ${ }^{2}$ Department of Botany, P.G. Campus, Tribhuvan University,, Biratnagar \\ EE-mail: dhakalmr@rediffmail.com
}

\begin{abstract}
Effect of cement dust pollution on crop productivity in the environment of Himal Cement Factory, Kathmandu, Nepal has been studied. The productivity of the crops like wheat, maize and mustard were significantly low in the fields $1.5 \mathrm{~km}$ around the factory site in comparison to the fields at 3-4-km distance. Productivity of rice was least affected. Polluted area around the cement factory becomes unsuitable for vegetable production due to deposition of dust particles on the leaves. A list of plants growing around the factory has also been presented.
\end{abstract}

Key words: Air pollution, vegetation, crop productivity, cement dust.

\section{Introduction}

Suspended particulate matter and gaseous chemicals are the main forms of air pollution that are potential health and ecological hazards. Cement dust is a localized air pollution problem in the vicinity of a cement factory. Dust particles from the limestone mines, coal yards and cement clinkers are emitted into the air, together with dust from various processes such as crushing and clinkerisation. Heavy encrustation of cement dust is formed on the plants growing in cement polluted area. This dust coverage reduces the growth of the plants (Oblisami et al., 1978), and brings physiological disorder to vegetation, which is responsible for the reduction of chlorophyll content and photosynthetic activities (Pandey \& Kumar, 1996; Pandey \& Simba, 1990 a; b) ultimately resulting in commensurate yield reduction. The loss due to the reduced agricultural production in vicinity of a cement factory might be of considerable significance not only in the economy of the people inhabiting these areas but in the economy of the whole country as well. An estimation of this economic loss in terms of reduced production of cultivated crops in the area affected by the dust emission of the cement factory is highly desired.

Certain plants are more sensitive to air pollution and used as indicators of the pollution (Brandt \& Heck, 1968; LeBlanc \& Rao, 1975). Prolonged exposure of the plants to cement dust might cause certain sensitive plants to disappear from the locality and if such plants are rare and endangered it could be a great loss of biodiversity resources. Heitherto, no attempt has been made to keep a record of the vegetation around a cement factory. Present paper presents a list of the plants growing within $4 \mathrm{~km}$ distance around a cement factory in Nepal together with a comparison of the crop productivity between dust polluted and dusts free area.

\section{Material and Methods}


The study area is situated in the environment of the Himal Cement Factory, at Chobhar near Kirtipur, $5 \mathrm{~km}$ south-west of Kathmandu, Nepal. Commissioned in 1974, the company has expanded its production capacity from 60 to 400 tonnes of clinker per day. The company estimates an average emission of 2.85 tonnes of dust per $24 \mathrm{~h}$ from the stack and around 10 tonnes of dust from limestone handling from the query site (Bhattarai, 1993). Himal Cement Factory also contributes to air quality degradation in Kathmandu Valley (NCP/ IUCN, 1993).

Plant specimens were collected from the area $4 \mathrm{~km}$ around the factory site and identified by comparing with the specimens at National Herbarium and Plant Laboratory, Godawari, Kathmandu, Lalitpur, Nepal. The sampling procedure was adopted in the two different steps to obtain the baseline survey data. The first step was to select villages that are having true chance of exposures and are nearer (within 0-1.5 km) to the factory and considered as dust affected area. The second was to select the villages that could be considered as pollution free area (within 3-4 km periphery from the factory) as no trace of the dust could be seen deposited on the plant surfaces. A semi-structured questionnaire was prepared for farmers and local people to find out information on general effects of the pollution that they are facing, and area and yield under cultivation. The data for land area and production were pooled separately from the two sites (polluted and pollution free) and average productivity was calculated on that basis. Three villages of Kathmandu districts (Upalloguth, Talloguth, Lapsibot) and four of the Lalitpur districts (Thapagaun, Pakhagaun, Thanagaun, Tokhaphant) were taken from the polluted site whereas from the pollution free zone Bhajangal, Panga, Itagol, Taudaha (Kathmandu district), Chalnakhel and Saibupakhagaun (Lalitpur districts) were sampled. Foliar injuries were observed by visual inspection in the field.

\section{Results}

\section{Vegetation}

In the study area 118 different species of plants (Table 1) were recorded of which two are the plants which have been enlisted as rare and vulnerable plants by Shrestha (1996). On the basis of frequency of collection rest of the plants are recorded as very common (VC), common $(\mathrm{C})$ and seldom available (Sa). Collection was also made of the plants planted inside the complex of the factory, from where 17 plants were recorded out of which eight were exotic trees (Table 2).

Table 1. Enumeration of plants growing within $1.5 \mathrm{~km}$ periphery of Himal Cement Factory. $\mathrm{C}=$ Common, $\mathrm{VC}=$ Very common, $\mathrm{Sa}=$ Seldom available, $\mathrm{V}=$ Vulnerable, $\mathrm{R}=$ Rare.

\begin{tabular}{lllc}
\hline Botanical name & Family & Common name & Abundance \\
\hline Achyranthes aspera L. & Amaranthaceae & Apamarga & C \\
Adhatoda vasica Nees & Acanthaceae & Asuro & C \\
Agave americana L. & Amaryllidaceae & Ketuki & C \\
Ageratum conyzoides L. & Compositae & Ilame & C \\
Albizzia procera (Roxb.) Benth. & Mimosaceae & Siris & C \\
Alnus nepalensis D. Don & Betulaceae & Utis & C \\
Amaranthus viridis L. & Amaranthaceae & Latte & C \\
Amaranthus spinosus L. & Amarantheceae & Lunde & C \\
Artemisia vulgaris Linn. & Compositae & Titepati & VC \\
Berberis aristata DC. & Berberidaceae & Chutro & C \\
Bidens pilosa L. & Compositae & & C \\
Boehmeria sp. & Urticaceae & Kamle & C
\end{tabular}


Boenninghausenia albiflorra (Hook.) Meisn. Rutaceae

Bombax malabaricum DC.

Bambaceae

Simal

$\mathrm{C}$

Buddleja asiatica Lour.

Cannabis sativa $\mathrm{L}$.

Loganiaceae

Cassia tora $\mathrm{L}$.

Celtis australis $\mathrm{L}$.

Cannabinaceae

Caesalpinaceae

Ulmaceae

Bhanj

Umbelliferae

Centella asiatica $(\mathrm{L})$ Urban

Compositae

Centipedia minima (L)A.Br.et Aschers

Solanaceae

Chenopodium album $\mathrm{L}$.

Chenopodiaceae

Choerospondias axillaris Burtt et Hill.

Cinnamomum camphora (L) Sieb.

Cirsium sp

Cissampelos pareira $\mathrm{L}$.

Citrus grandis Linn.

Colebrookea oppositifolia J.E. Smith

Conyza sp.

Cuscuta reflexa roxb.

Cyathocline purpurea $\mathrm{O}$. Kuntz

Cynodon dactylon (L.) Pers.

Anacardiaceae

Lauraceae

Compositae

Menispermaceae

Rutaceae

Labiatae

Compositae

Cuscutaceae

Compositae

Gramineae

Cynoglossum zeylanicum Thunb. ex Lehm. Boraginaceae

Dendrocalamus sp.

Duranta repens L.

Gramineae

Verbenaceae

Eclipta prostrate L.

Eupatorium adenophorum Spreng

Compositae

Compositae

Equisetum diffusum D. Don

Equisetaceae

Eragrostis sp.

Gramineae

Erigeron bellidioides Benth ex C.B. Clarke Compositae

Eucalyptus cameldulensis Dehn.

Myrtaceae

Euphorbia heterophylla L.

Ficus sp.

Fragaria indica Andr.

Fraxinus floribunda Wall. in Roxb.

Galinsuga ciliata (Rafin)Blake

Euphorbiaceae

Moraceae

Rosaceae

Oleaceae

Compositae

Geranium nepalense Sweet

Gnaphalium purpureum L.

Gonostegia hirta (Blume) Miq.

Geraniaceae

Compositae

Urticaceae

Grevillea robusta A. Cunn.

Proteaceae

Hibiscus rosa-sinensis L.

Homalium nepaulense (DC.) Benth.

Imperata cylindrica (L.) Beauv.

Malvaceae

Flacourtiaceae

Gramineae

Ipomoea purpurea (L.) Roth

Jasminum humile L.

Juglans regia L.

Lagerstroemia indica $\mathrm{L}$.

Lantana camera $\mathrm{L}$.

Ligustrum confusum Decaisn

Maesa chisia Buch.-Ham. Ex D. Don

Magnolia grandiflora $\mathrm{L}$.

Melia azedarach $\mathrm{L}$.

Mussenda frondosa L.

Convolvulaceae

Oleaceae Jai

Juglandiaceae

Lythraceae

Khari

Ghodtapre

Bethu
Lapsi
Kapur

$\mathrm{Sa}$

$\mathrm{C}$

$\mathrm{VC}$

$\mathrm{C}$

$\mathrm{VC}$

$\mathrm{C}$

$\mathrm{C}$

$\mathrm{C}$

$\mathrm{C}$

$\mathrm{C}$

$\mathrm{C}$

$\mathrm{C}$

$\mathrm{Sa}$

Bhogate $\quad \mathrm{C}$

Dhursul C

$\mathrm{C}$
$\mathrm{C}$

Chhichhine C

Dubo VC

Bans $\quad \mathrm{C}$

Nilkanda $\quad$ VC

Bhringiraj $\quad \mathrm{C}$

Banmara VC

C

C

C

$\mathrm{C}$

C

$\mathrm{C}$

$\mathrm{C}$

Lankuri $\mathrm{C}$

Verbinaceae

Olaceae

Myrsinaceae

Magnoliaceae

Meliaceae

Rubiaceae

Nasturtium officinal R.Br. ex Aiton

Oenothera erythrosepala Borbas

Cruciferae

Onagraceae

Oxalidaceae

Oxalis corniculata L.

Plantaginaceae

Okhar

Asare

Aternu

Kangiyo

Ghantephul

$\mathrm{VC}$

C

C

C

C

C

V

C

C

C

$\mathrm{Sa}$

$\mathrm{Sa}$

C

C

Bilaune $\quad \mathrm{Sa}$

Thalkamal Sa

Bakaino C

Plantago major Linn.

Simsag C


Paspalum sp.

Phragmites karka Trin ex Steud.

Pinus roxburghii Sargent

Plumbago zeylanica $\mathrm{L}$.

Pogonatherum crinitum (Thunb.)Kunth

Polygonum perfoliatum L.

Polygonum sp.

Populus sp.

Princepia utilis Royle

Prunus persica Sieb. et Zucc.

Pteris longifolia Aucct.

Punica granatum L.

Pyracantha crenulata (D.Don) Roem

Pyrus communis L.

Pyrus malus L.

Ranunculus sceleratus $\mathrm{L}$.

Rhus javanica $\mathrm{L}$.

Rhus parviflora Roxb.

Rosa microphylla Lindle

Rubia cordifolia $\mathrm{L}$.

Rubus ellipticus J.E. Smith

Rubus paniculatus J.E. Smith

Rumex nepalensis Spreng.

Saccharum spontaneum L.

Salyx babylonica L.

Sambucus hookeri Rehder in Sarg.

Sapium insigne Benth ex Hook.f.

Scutellaria discolor Celebr.

Setaria sp.

Solanum nigrum L.

Solanum sp

Gramineae

Gramineae

Narkat

Pinaceae

Sallo

C

Plumbaginaceae

Gramineae

Polygonaceae

Polygonaceae

Salicaceae

Rosaceae

Rosaceae

Pteridaceae

Punicaceae

Rosaceae

Rosaceae

Rosaceae

Ranunculaceae

Anacardiaceae

Anacardiaceae

Rosaceae

Rubiaceae

Rosaceae

Rosaceae

Polygonaceae

Gramineae

Salicaceae

Caprifoliaceae

$\mathrm{C}$

C

$\mathrm{C}$

$\mathrm{C}$

Lahrepipal C

C

Painyu $\quad \mathrm{C}$

C

Anar $\quad \mathrm{C}$

Ghangaru $\quad \mathrm{C}$

Naspati C

C

$\mathrm{VC}$

Bhakimlo Sa

Satibayar $\quad \mathrm{Sa}$

$\mathrm{C}$

Majito $\quad \mathrm{Sa}$

Ainselu C

Euphorbiaceae

Labiatae

Gramineae

Solanaceae

Solanaceae

Solanum xanthocarpum Schrad et Wendl.

Solanaceae

Soncus arvensis $\mathrm{L}$.

Compositae

Caryophyllaceae

Halhale

$\mathrm{C}$

Kansh

$\mathrm{VC}$

Bains

Jaliphul

Khirra

Menispermaceae

Stephania glandulifera Miers

Thelypteridaceae

Thelptyeris ciliata (Wall. ex Benth.) Ching

Toona ciliate M. Roem

Meliaceae

Papilionaceae

Trifolium repens $\mathrm{L}$.

Urtica dioica Linn.

Vitex negundo L.

Zanthoxylum armatum DC.

Zizyphus incurva Roxb.

Urticaceae

Verbinaceae

Rutaceae

Rhamnaceae

Zizyphus jujube Lam.

Rhamnaceae

Datura

Kantakari

Dhude

C

C

C

C

C

$\mathrm{VC}$

C

C

C

C

C

$\mathrm{Sa}$

C

$\mathrm{R}$

$\mathrm{VC}$

C

C

$\mathrm{Sa}$

$\mathrm{VC}$

Table 2. Plants growing inside the complex of the cement factory. * = Exotic

\begin{tabular}{ll}
\hline Botanical name & Family \\
\hline Alnus nepalensis D. Don & Betulaceae \\
*Alnus nitida (Spach.) Endl & Betulaceae \\
Callistemon citrinus (Curtis) Skeels & Myrtaceae \\
Celtis australis L. & Ulmaceae \\
\hline *Cinnamomum camphora (L.) Sieb. & Lauraceae \\
Duranta repens L. & Verbinaceae \\
*Eucalyptus cameldulensis Dehn. & Myrtaceae \\
Fraxinus floribunda Wall. in Roxb. & Oleaceae
\end{tabular}




\begin{tabular}{ll} 
*Grevillea robusta A.Cunn. ex R.Br. & Proteaceae \\
*Jacaranda mimosaefolia D. Don. & Leguminosae \\
Juniperus sp. & Pinaceae \\
Pinus roxburghii Sargent & Pinaceae \\
*Populus deltoids Marsh & Salicaceae \\
*Salix babylonica L. & Salicaceae \\
Sapium insigne (Royle) Benth. ex Hook. f. Euphorbiaceae \\
Sambucus hookeri Rehder in Sarg. & Caprifoliaceae \\
Zizyphus incurva Roxb. & Rhamnaceae \\
\hline
\end{tabular}

\section{Problems associated with dust as perceived by the local community}

Mechanical turbulence and poor sunlight during winter are most prominent problems, which create a direct problem to the farmers in their usual practice of sun drying their crops like rice, wheat etc. There is more serious effect on winter crops (Nov.- Feb.) as rainfall is poor to wash the dust and thus dust remain deposited for longer time over the foliage of plants.

The problem is serious $1 \mathrm{~km}$ from the factory site. People around the factory report that there is more roadside accident near to the factory. Due to heavy deposition of dust, no vegetable cultivation could be carried out in the severely affected area and the straw of rice, wheat and barley is not palatable to livestocks. Livestocks suffer from diseases if they are fed on the straws for a long time. In Tokhaphant there is a problem of threshing rice as no workers are available to thresh rice because of cement dust.

\section{Foliar enjury}

Following observations were made during site survey

a) The ventral part of the leaves is not exposed to rain water, so a layer of dust deposition is seen even after continuous rain.

b) From visual inspection it was observed that most affected plants were Pinus roxburghii and the color of the leaves of $P$. roxburghii look different from that of a normal tree.

c) Abrasions caused by cement dust were found on broad-leaved trees and leafy vegetables. But no serious diseases could be observed in the field.

\section{Productivity}

The average productivities of different crops from the polluted and pollution free zones are compared in Table 3.

Rice was found to be relatively resistant to the cement dust pollution. Although the data shows less production of rice in polluted area the difference is not significant. Maize and wheat are most affected crop where 66.7 and $62.1 \%$ reduction is recorded, respectively in these crops. Mustard is also highly affected where a reduction up to $26.6 \%$ was observed.

Farmers reported that Millet was in cultivation in the polluted area up to 8-10 years ago. But, due to the dust problems no millet farming is seen in this area. No leafy vegetables were observed cultivated in the heavily polluted area.

Table 3. Comparison of the productivity of different crops in the polluted and pollution free areas. \pm SD

\begin{tabular}{lccc}
\hline \multirow{2}{*}{ Crops } & \multicolumn{2}{c}{ Productivity $(\mathrm{Kg} /$ Ropani*) } & Reduction \\
\cline { 2 - 3 } & Polluted area & Non polluted area & $\%$ \\
\hline Rice & $217 \pm 19.8$ & $231 \pm 33$ & 6.1 \\
\hline
\end{tabular}




\begin{tabular}{lccc}
\hline Wheat & $99 \pm 1.7$ & $264 \pm 40$ & 62.1 \\
Maize & $33 \pm 11.8$ & $99 \pm 1.7$ & 66.7 \\
Millet & - & $66 \pm 9$ & - \\
Barley & - & $99 \pm 1.7$ & - \\
Mustard & $18.2 \pm 1.7$ & $24.8 \pm 8.3$ & 26.6 \\
Potato & $151.8 \pm 19.8$ & $165 \pm 1.7$ & 8.5 \\
\hline
\end{tabular}

*1 Ropani $=5476 \mathrm{Sq} \mathrm{ft}$.

\section{Discussion}

In order to improve economic and social well being, many developing countries give priority to rapid industrial development. Although it can lead to progress and improved quality of life, it can also produce serious environmental deterioration if not carefully controlled (Karmacharya \& Shrestha, 1993). The economic costs related to air pollution are manifested in different ways. One of the significant effects is that it might affect the physiological life of the plants to such an extend that the sensitive plant may die and ultimately its population disappear from the polluted locality (Darley, 1966; LeBlanc \& Rao, 1975). Air pollution from a cement factory could cause immeasurable loss if some endemic or threatened plants that are sensitive to pollution are growing in the area. As no previous record of the vegetation of the locality is available, present study is a first attempt to keep a record of the vegetation growing in the vicinity of a cement factory in Nepal.

The major air pollutants of the cement factory are particulate and gaseous wastes such as $\mathrm{SO}_{2}, \mathrm{CO}$ and $\mathrm{NO}_{2}$, which are emitted from chimneys or smoke stakes. Dust emitted generally contains carbonate, silicate, aluminate fluoride and alkalihalides (NCP/IUCN, 1993). The limestone required for the Himal Cement Factory comes from the limestone deposits of Chobhar hills. ISC (1987) reported that the flue gas emitted from the cement kiln before the factory's expansion (1989) contained various gaseous compounds including $\mathrm{NO}(200 \mathrm{ppm}), \mathrm{NO}_{2}(30 \mathrm{ppm})$ and $\mathrm{SO}_{2}(5 \mathrm{ppm})$. Carbondioxide form $16 \%$ of the flue gas and $\mathrm{CO}, 2-6 \%$. Emission of $\mathrm{NO}_{2}$ and $\mathrm{SO}_{2}$ were within international standards but the dust emission was high even from the new kiln (Miyoshi, 1987). Dust is also emitted from the limestone crusher, saw mill, raw material storage yard and limestone excavation processes. These emissions have not been measured.

Meteorological parameters such as wind speed and direction, vertical temperature gradient and flux were not available and thus dispersal rates and area could not be calculated. Visual observation showed that a layer of dust remains deposited on the lower surface of the leaves even after heavy rainfall during the rainy season. Himal (1987) reported that depending on the wind conditions, Chobhar village near the factory and Saga village across the Bagmati river were enveloped in dust and the area looked whitish gray. The lack of adequate dust collectors was cited as the reason for high dust emission.

Effects of cement kiln dust on various aspects of plant life have been studied by various workers (Pierce, 1910; Oblisami et al., 1978; Singh \& Rao, 1978; Pandey \& Simba, 1990 a; b; Pandey \& Kumar, 1996). These works conform that dust pollution affects the growth and different physiological processes of the plants which is the ultimate cause of the yield reduction. Our survey and analysis of the collected data on productivity of various crops showed that productivity of the land around cement factory is considerably low as compared to the lands at a distance from the factory. Productivity of crop plants depends on various factors of which two significant factors are the quality of the land itself and the use of fertilizers. In the present survey all the possible attention was paid to ascertain that 
the general quality of land in which the crops were grown falls in the same category. Although the judgement was based on local farmer's information, considering the fact that in villages the buying and selling of lands is generally based on the average productivity, it is expected that the average data on the productivity could be more or less uniform and reliable. The area considered as polluted is inhabited by poor farmers who use only the animal dung as fertilizers. A few farmers on pollution free villages use chemical fertilizers. However, these cultivation's were excluded from the present survey to keep uniformity on the results.

The health hazards due to the dust pollution of a cement factory are obvious and well known. Our observation shows that in addition to other problems, there is a general loss of crop productivity in the land around a cement factory. Wheat, maize and mustard crops are seriously affected and the area around the factory becomes totally unsuitable for vegetable production. Even the paddy hay and wheat straws become unpalatable to the livestocks. Thus it is desirable that while establishing a factory the economic loss due to its pollution be considered in totality and compare to the economic upliftment due to the industrial production.

\section{Acknowledgements}

Financial assistance for conducting the present study by Environment and Public Health Organization (ENPHO), Nepal is highly acknowledged.

\section{References}

Bhattarai, M.D. 1993. Paper on industrial contribution to air quality. In: First Urban Air Quality Management Workshop (URBAIR). Ministry of Industry, Kathmandu, Nepal. pp. 1-12.

Brandt, C.S. \& W.W. Heck. 1968. Effect of air pollution on vegetation. In: Air pollution, I (Ed. A.C. Stern). Academic Press, New York. pp. 401-493.

Darley, E.F. 1966. Studies on the effect of cement kiln dust on vegetation. J. Air Pollut. Control Assoc. 16: 145-150.

Himal. 1987. The valley chokes- Pollution in Kathmandu. Himal prototype issue. pp. 3-8.

ISC. 1987. Study report on industrial pollution control. Report prepared for Ministry of Industry, Industrial Services Centre, Kathmandu, Nepal.

Karmacharya, A.P. \& R.K. Shrestha. 1993. Air quality assessment in Kathamndu city. Environment \& Public health organization (ENPHO), Kathamndu (Project report).

LeBlanc, F. \& D.N. Rao. 1975. Effect of air pollution on lichens and bryophytes. In: Responses of plants to air pollution (Eds. J.B. Mudd \& T.T. Kozloswki). Academic Press, New York. pp. 237-272.

Miyoshi, Y. 1987. Study report on industrial pollution control. Industrial Services Center (now, Economic Services Centre; ESEC) Kathmandu.

NCP/IUCN. 1993. Air pollution. In: Environment pollution in Nepal. NCP/ IUCN/ NCS Programme, Kathamndu, Nepal. pp. 19-22.

Oblisami, G., G. Pathmanabhan \& C. Padmanabhan. 1978. Effect of particulate pollutant from cement Kiln on cotton plants. Indian J. Air Poll. Cont. 1: 91-94.

Pandey, D.D. \& A.K. Simba. 1990a. Effect of cement kiln dust on chlorophyll in wheat leaf. Environment \& Ecology 14(4): 461-463.

Pandey, D.D. \& A.K. Simba. 1990b. Effect of cement kiln dust on chlorophyll in maize leaf. Geobios 17: 40-41.

Pandey, D.D. \& S. Kumar. 1996. Impact of cement dust pollution on biomass, chlorophyll, nutrients and grain characteristics of wheat. Environment \& Ecology 14(4): 872-875. 
Pierce, C.J. 1910. An effect of cement dust on orange trees. Plant World 13: 283-288.

Shrestha, T.B. 1996. Rare, endemic and endangered plants of Nepal. WWF, Nepal Programme.

Singh, S.N. \& D.N. Rao. 1978. Possibilities of using chlorophyll and potassium contents in plants to detect cement dust pollution. Indian J. Environ. Hlth. 20: 10-13. 